Available online at GSC Online Press Directory

GSC Biological and Pharmaceutical Sciences

e-ISSN: 2581-3250, CODEN (USA): GBPSC2

Journal homepage: https://www.gsconlinepress.com/journals/gscbps

(RESEARCH ARTICLE)

\title{
Chromosomal aberrations induced by cassava industrial effluent using Allium Cepa assay
}

Gbenga Olorunshola Alege 1,* Chinenye Sylvia Anyoku 2, Comfort Kehinde Olubiyo ${ }^{3}$, Gloria Taiye Olubiyo 4 , Blessing Adejoh ${ }^{2}$ and Daniel Yomi Onemayin ${ }^{4}$

${ }^{1}$ Department of Biotechnology, Federal University Lokoja, Kogi State, Nigeria.

2 Department of Biological Sciences, Federal University Lokoja, Kogi State, Nigeria.

${ }^{3}$ Department of Animal and Environmental Biology, Kogi University, Anyigba, Kogi State, Nigeria.

${ }^{4}$ Department of Plant Science and Biotechnology, Kogi University, Anyigba, Kogi State., Nigeria.

Publication history: Received on 25 November 2020; revised on 05 December 2020; accepted on 07 December 2020

Article DOI: https://doi.org/10.30574/gscbps.2020.13.3.0386

\begin{abstract}
This study assessed the heavy metal compositions and chromosome aberrations induced by cassava industrial effluent using Allium cepa meristem assay. Effluent collected at the point of discharge from the cassava processing factory located at Lokoja, Kogi State Nigeria was analyzed for quantity of Cadmium (Cd), Chromium (Cr), Copper (Cu), Manganese (Mn), Iron (Fe), Nickel Ni, Cobalt (Co) and Lead (Pb) using Atomic Absorption Spectrophotometer method. Onion (Allium cepa) roots were allowed to grow in beakers containing different concentrations of cassava industrial effluent (i.e. $25 \%, 50 \%, 75 \%$ and $100 \%$ ) and the control for 24 hours. Harvesting of the tips for chromosome observations was carried out between 8:00 to 9:00am West Africa Time. Data pooled under X400 magnification of the light microscope for mitotic phases and chromosome aberrations were analyzed using Analysis of Variance (ANOVA) while means with significant difference across concentrations were separated using Duncan Multiple Range Test (DMRT). The results revealed that only Cadmium (Cd) and Lead (Pb) concentrations in the effluent were higher than the minimum values recommended by World Health Organization. The effluent also produce binucleate cells, variant chromosomes, C-mitosis, vacuolated cells, tripolar anaphase and anaphase bridge which suggests the mutagenic and cytotoxic activities of the industrial effluent. The decrease in the Mitotic Indices (MI) of effluent-treated root cells compared to the control indicates mito-depressive ability of the effluent at every concentration. Regular monitoring of industries for compliance to treatment of effluent before releasing them into the environment is recommended.
\end{abstract}

Keywords: Heavy metal; Effluent; Aberration; Allium cepa; Mitodepressive

\section{Introduction}

Industrial growth in Nigeria has been of great benefit to the nation but indiscriminate discharge of wastewater generated from these industries into the environment has posed serious health and environmental issues [1,2]. Punitive measures are not taken on industries that discharge hazardous waste into the environment because industrialization has been regarded as a major index to national growth [3]. Wastes generated from industrial activities as noted by [4] contribute significantly to environmental irritation and pollution. Most of these wastes are generated in form of effluent which according to [5] are mutagenic and capable of causing serious human diseases. Proper management of industrial effluent to reduce the risks associated with them was suggested by [6]. The untreated or partially treated effluents generated from industries are usually discharged indiscriminately into the aquatic system [7]. This obviously predisposes aquatic ecosystems to heavy metal pollutants which could enter human systems through the food chain [8].

\footnotetext{
${ }^{*}$ Corresponding author: Gbenga Olorunshola Alege

Department of Biotechnology, Federal University Lokoja, Kogi State, Nigeria.
}

Copyright (C) 2020 Author(s) retain the copyright of this article. This article is published under the terms of the Creative Commons Attribution Liscense 4.0. 
High concentration of heavy metals capable of causing aberrations in living systems has been associated with most of the industrial effluents [9].

According to [10] and [11] the main source of heavy metal contamination in aquatic ecosystems are anthropogenic activities. Increase in heavy metal concentration in water bodies is now becoming serious threat to human and aquatic ecosystems [12,13]. According to [8] when heavy metal concentrations exceed environmental tolerance limits, use of such water for agricultural (irrigation and aquaculture) activities could pose serious harm to environmental and human health. The common heavy metals of health concern to humans according to [14] are Arsenic, Cadmium, Chromium, Lead, Nickel and Zinc. Exactly a decade ago, [15] envisaged that water contamination by heavy metals is likely to increase rapidly beyond tolerance limits if best practices are not put in place. Since very little has been done to curtail this, heavy metal contamination of water bodies have been reported by [7] to be a serious issue of global concern from environmental and human health perspectives. Industrial waste water (effluent) is without doubt one of the important sources of heavy metal pollution to aquatic $[6,16]$.

Products derived from cassava are the principal source of food for about 500 million to 1 billion people in tropical countries [17]. The quest to increase the uses, improve the shelf-life, flavor, taste and reduce the cyanide content of cassava has brought about several traditional and industrial processing techniques. According to [4], the three common traditional products obtained from fermented cassava tubers in Nigeria are 'garri', 'lafun' and 'akpu'. Other important uses of cassava in Nigeria include production of 'farinha', 'attieke', starch, bread, chips, e.t.c [18]. Industries like breweries, feed mills, ethanol plants and paper mills also use cassava as their raw materials [19].

Plant based bioassays are the most preferred biological assay for the screening and monitoring of hazardous pollutants in the environment $[3,20,21]$. The preference of plant based bioassay over other biological assays could be attributed to its cheap, rapid detection of minute alteration in the quality of water and use of simple laboratory equipment for the investigation [22]. Allium bioassay according to [23] have been shown to correlate well with other bioassay systems and therefore proved to be an excellent indicator of toxicity. The comparableness in response of plant and mammalian cells to cytotoxic agents in the opinion of [21] has been attributed to the structural similarities of chromosomes. IIbas et al. [24] buttressed this by stating that the deformities observed in onion root tips treated with mutagenic chemicals are also detected in human cells since both onion and human genomes contains DNA. According to [20] mitotic index and type/rate of chromosomal abnormalities are two common markers used to evaluate the cytotoxicity and genotoxicity of mutagenic agents. Allium cepa (onion) is frequently employed for the assessment of environmental risk because it contains few numbers of chromosomes that are large enough to present clear elucidation of chromosome aberrations $[25,26,27]$.

The cytotoxic potential of wastewater produced after traditional fermentation of cassava tubers to produce 'lafun', 'garri' and 'akpu' was assessed by [4]. Studies on the toxicity of effluent generated from industrial processing of cassava have not been given the required attention. Since the bulk of the pollution experienced today comes from indiscriminate discharge of industrial effluent to the environment compared to traditional wastewater discharge, the former therefore deserves urgent attention. No cytotoxic study on effluent generated from any industry in Lokoja, Kogi State, Nigeria using Allium cepa chromosome aberration assay has been conducted hence findings from this study will generate baseline data for environmental monitoring and pollution control in the study area. Against this background, effluent from cassava processing industry in Lokoja, Kogi State was considered for this study. The industry extracts ethanol from cassava and discharge the wastewater directly into the River Niger through a large pipe. Fishing and irrigation farming is the major occupation of people living around this polluted river. Assessing the impact of this effluent on genetic systems is very germane since humans consume the aquatic products and crops grown with the polluted water. This study therefore aimed at determining heavy metal compositions and chromosome aberrations associated with cassava industrial effluent using Allium cepa root tip assay.

\section{Material and methods}

\subsection{Sample Collection}

The effluent considered for this study was aseptically collected into sterile bottles at the point of discharge from the cassava processing factory located at Lokoja, Kogi State Nigeria. Allium cepa (onion) bulbs of fairly equal sizes were purchased from International market Lokoja, Kogi State. 


\subsection{Heavy Metal Analysis}

Eight heavy metals (Cadmium, Chromium, Copper, Manganese, Iron, Nickel, Cobalt and Lead) were analyzed using Atomic Absorption Spectrophotometer (AAS) method described by [28].

\subsection{Preparation of test sample}

A total of twenty five healthy Allium cepa bulbs of fairly equal sizes were rinsed with water and the dry scaly leaves were removed. In order to hasten the development of roots, dried roots were cautiously removed. The reduced stems in lower parts of the bulbs were thereafter allowed to make contact with distilled water in the beakers after dissecting the onion bulbs transversely. The upper parts of the dissected onion bulbs were discarded. To maintain uniform genotypes, the dissected onions were allowed to sprout shoots and only onions bulbs that sprouted up to five small onions sets were selected for further study. The onion set were transferred into the beakers containing different concentrations of cassava industrial effluent (i.e. $25 \%, 50 \%, 75 \%$ and $100 \%$ ). The roots were removed from the treatments after 24 hours and washed thoroughly. Only the roots measuring about $1 \mathrm{~cm}$ in length were harvested into vials between the hours of 8:00 to 9:00am WAT. Each treatment had five replicates and followed Complete Randomized Design (CRD) arrangement. The methods outlined by [29] were adopted for fixation, hydrolysis, squashing and staining of root tips.

\subsection{Fixation}

The fixative is made up of ratio 1:3 of glacial acetic acid and absolute ethanol. Fixation is meant to keep the cells in their natural states. The fixed root tips remained in labeled vials and are kept in the refrigerator until when needed.

\subsection{Hydrolysis}

The root tips were removed from fixatives and properly washed with distilled water. Hydrolysis using $10 \% \mathrm{HCl}$ at $60^{\circ} \mathrm{C}$ in water bath was carried out to soften the root tips.

\subsection{Squashing and staining}

The root tips were thoroughly washed with distilled water to remove $10 \% \mathrm{HCl}$. The washed root tips were placed one at a time on the glass slide for squashing. The older parts of the root tips were cut with blade and discarded while the meristematic tips remaining on the slide were stained with two drops of aceto-carmines and covered with cover slips. Squashing of meristems was carried out using the flat end of a cylindrical search needle until a turbid suspension was obtained. By carefully applying pressure on the filter paper used to fold the specimen between the slide and the cover slip, excess stain was drained off. Transparent nail polish was applied to the edges of the cover slip to make the specimen air-tight. Five different slides were prepared for each treatment using the described methods.

\subsection{Chromosome observation}

Each slide was carefully studied under the Celestron Digital model of the light microscope. Three different objectives $(\mathrm{X} 4, \mathrm{X} 10, \mathrm{X} 40)$ were used to examine the slides. Photomicrographs of different stages of cell division and abnormal cells were taken using X40 magnifications.

\subsection{Data Analyses}

For each of the different concentrations of the industrial effluents, ten microscopic counts were taken from five different prepared slides. This was taken for normal mitotic stages and aberrant conditions. Data obtained were subjected to Analysis of Variance (ANOVA) and Duncan Multiple Range Test (DMRT) using Post hoc test with SPSS version 23. The Mitotic Index (MI) and Percentage of Aberrant Cells (PAC) for the effluent treated cells and control were calculated using the formulae outlined by [30] and presented in a bar chart.

$$
\text { Mitotic Index }(M I)=\frac{\text { Total number of dividing cell }}{\text { Total numberof cells examined }} \times 100
$$

Percentage of Aberrant Cells $(P A C)=\frac{\text { Total number of abnormal cells }}{\text { Total numberof cells examined }} X 100$ 


\section{Results}

Table 1 shows the heavy metal composition of the cassava industrial effluent. From the table Arsenic (As) and Selenium (Se) were not detected in the effluent while Chromium $(0.026 \pm 0.004 \mathrm{ppm})$ and Copper $(0.012 \pm 0.002 \mathrm{ppm})$ were detected but their values were not above the permissible level of World Health Organization (WHO). Only the values of Cadmium $(0.080 \pm 0.001 \mathrm{ppm})$ and Lead $(0.029 \pm 0.002 \mathrm{ppm})$ detected in the effluent were found to be above the World Health Organization (WHO) permissible levels (Table 1).

Table 1 Heavy metal concentrations of effluent obtained from the cassava processing company

\begin{tabular}{|l|l|l|l|l|l|l|}
\hline Parameter & $\begin{array}{l}\text { Arsenic } \\
\text { (As) }\end{array}$ & $\begin{array}{l}\text { Cadmium } \\
(\mathbf{C d})\end{array}$ & $\begin{array}{l}\text { Chromium } \\
(\mathbf{C r})\end{array}$ & $\begin{array}{l}\text { Copper } \\
(\mathbf{C u})\end{array}$ & $\begin{array}{l}\text { Lead } \\
(\mathbf{P b})\end{array}$ & $\begin{array}{l}\text { Selenium } \\
(\mathbf{S e})\end{array}$ \\
\hline $\begin{array}{l}\text { Quantity } \\
(\mathrm{pppm})\end{array}$ & ND & $0.080 \pm 0.001^{*}$ & $0.026 \pm 0.004$ & $0.012 \pm 0.002$ & $0.029 \pm 0.002^{*}$ & ND \\
\hline WHO & 0.01 & 0.003 & 0.05 & 2.00 & 0.01 & 0.01 \\
\hline \multicolumn{7}{|c|}{ ND= Not Detected } \\
\hline \multicolumn{7}{|c|}{ Values greater than the permissible level according to World Health Organization }
\end{tabular}

Table 2 and Figures 2A-K shows the effect of different concentrations of cassava industrial effluent on the cytological parameters of Allium cepa root meristematic cells. Ten out of the thirteen cytological parameters considered showed statistical significant difference $(\mathrm{P}<0.05)$ in relation to the different concentrations of cassava industrial effluent considered.

The cytological attributes with statistical significant differences at $\mathrm{P}<0.05$ are number of interphase, metaphase, telophase, binucleate cells, variant chromosomes, C-mitosis, vacuolated cells, tripolar anaphase, anaphase bridge and the total number of aberrant cells. Although $25 \%$ and $75 \%$ concentration of the effluent did not produce vacuolated cells while no binucleate cell was recorded in 50\% concentration. The three cytological attributes that did not show significant difference among the different concentrations of cassava industrial effluent in this study are total number of cells, number of prophase and number of anaphase.

From the same Table 2, it can be observed that the control group did not show any of the recorded chromosomal aberrations reported in this study. The production of aberrations was observed to be concentration dependent with highest concentration (100\%) producing the highest values for numbers of binucleate cells, vacuolated cell, faulty polarity, multiple bridges and total numbers of aberrant cells.

Table 2 Effects of cassava industrial effluent on cell division and chromosome abnormalities of Allium cepa root tip cells.

\begin{tabular}{|l|l|l|l|l|l|l|l|l|l|l|l|l|l|}
\hline Conc. & TC & NI & NP & NM & NA & NT & NB & NV & NC & ND & NL & NX & TZ \\
\hline Control & 111.90 & $70.10^{\mathrm{a}}$ & 29.10 & $4.10^{\mathrm{a}}$ & 2.50 & $13.20^{\mathrm{a}}$ & $0.00^{\mathrm{c}}$ & $0.00^{\mathrm{c}}$ & $0.00^{\mathrm{c}}$ & $0.00^{\mathrm{b}}$ & $0.00^{\mathrm{c}}$ & $0.00^{\mathrm{b}}$ & $0.00^{\mathrm{a}}$ \\
\hline $25 \%$ & 120.60 & $59.40^{\mathrm{ab}}$ & 30.20 & $2.50^{\mathrm{b}}$ & 4.40 & $6.50^{\mathrm{b}}$ & $0.20^{\mathrm{c}}$ & $4.50^{\mathrm{a}}$ & $1.70^{\mathrm{b}}$ & $0.00^{\mathrm{b}}$ & $2.60^{\mathrm{a}}$ & $0.60^{\mathrm{b}}$ & $9.60^{\mathrm{d}}$ \\
\hline $50 \%$ & 101.60 & $50.40^{\mathrm{bc}}$ & 25.00 & $1.30^{\mathrm{b}}$ & 3.90 & $7.30^{\mathrm{b}}$ & $0.00^{\mathrm{c}}$ & $1.56^{\mathrm{bc}}$ & $0.44^{\mathrm{c}}$ & $0.44^{\mathrm{b}}$ & $0.78^{\mathrm{b}}$ & $0.22^{\mathrm{b}}$ & $3.44^{\mathrm{b}}$ \\
\hline $75 \%$ & 113.40 & $44.20^{\mathrm{c}}$ & 28.00 & $2.00^{\mathrm{b}}$ & 3.70 & $6.10^{\mathrm{b}}$ & $0.70^{\mathrm{b}}$ & $2.70^{\mathrm{c}}$ & $1.60^{\mathrm{b}}$ & $0.00^{\mathrm{b}}$ & $1.50^{\mathrm{b}}$ & $0.40^{\mathrm{b}}$ & $6.90^{\mathrm{c}}$ \\
\hline $100 \%$ & 111.22 & $51.40^{\mathrm{bc}}$ & 31.50 & $2.30^{\mathrm{b}}$ & 2.6 & $7.90^{\mathrm{b}}$ & $1.40^{\mathrm{a}}$ & $3.20^{\mathrm{ab}}$ & $2.30^{\mathrm{b}}$ & $1.50^{\mathrm{a}}$ & $2.80^{\mathrm{a}}$ & $1.30^{\mathrm{a}}$ & $12.5^{\mathrm{e}}$ \\
\hline $\begin{array}{l}\text { LSD } \\
\text { Value }\end{array}$ & NS & 4.46 & NS & 0.49 & NS & 1.29 & 0.27 & 1.86 & 0.42 & 0.29 & 1.43 & 0.22 & 2.49 \\
\hline
\end{tabular}

Means with the same alphabets are not different statistically at $\mathrm{P}<0.05$

Keys: TC- Total number of cells; NI- Number of cells at interphase stage; NP- Number of cells at prophase stage; NM- Number of cells at metaphase stage; NA- Number of cells at anaphase stage; NT- Number of cells at telophase stage; NB- Number of binucleate cells; NV- Number of variant chromosomes; NC- Number of C-mitosis cells; ND- Number of vacuolated cells; NL- Number of tripolar anaphases; NX- Number of anaphase bridge; TZ- Total number of aberrant cells; LSD- Least significant difference; NS- Not significant

Figure 1 shows the effect of different concentrations of the industrial effluents on Mitotic Index and percentage of aberrant cells of Allium cepa root tip cells. Cells from the control roots produced the highest Mitotic Indices (MI) (47.49\%) while the lowest Mitotic Indices (MI) value of $35.10 \%$ was recorded for $75 \%$ concentration. Among the different concentrations of effluent, root tips treated with $100 \%$ cassava industrial effluent produced the highest Mitotic Index (39.83\%). The highest percentage of aberrant cells was recorded in $100 \%$ concentration (11.24\%) while no 
chromosomal aberration was recorded in control. Allium cepa root tips treated with $50 \%$ concentration of the industrial effluent produced the least percentage of aberrant cells (3.38\%) among the effluent-treated roots.

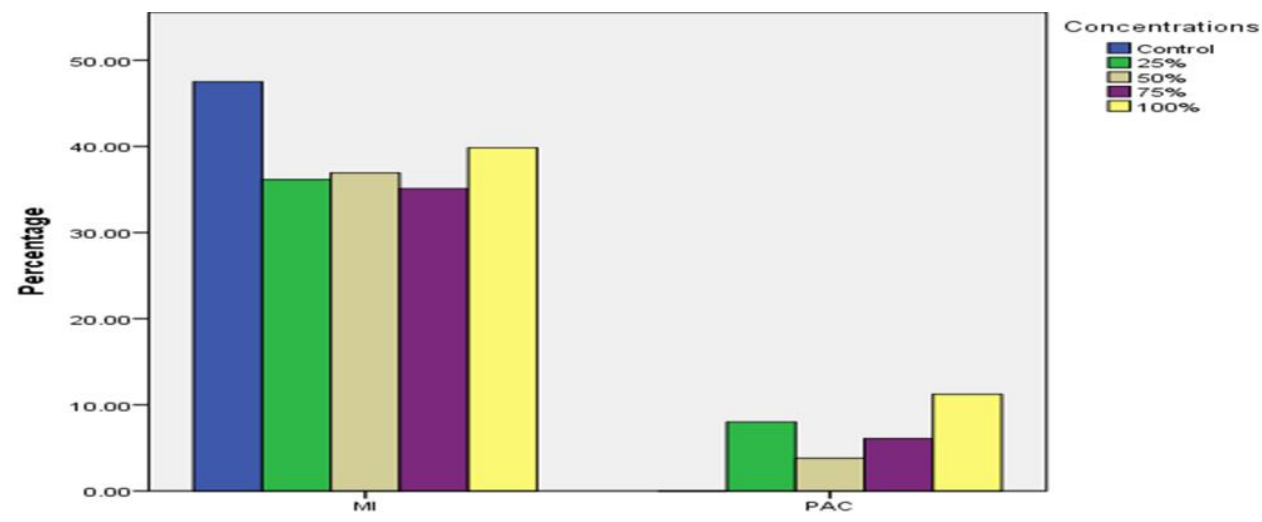

Figure 1 Mitotic Index and Percentage of Aberrant cells for Allium cepa root tip cells treated with different concentrations of cassava industrial effluents Key: MI= Mitotic Index; PAC= Percentage of Aberrant Cells
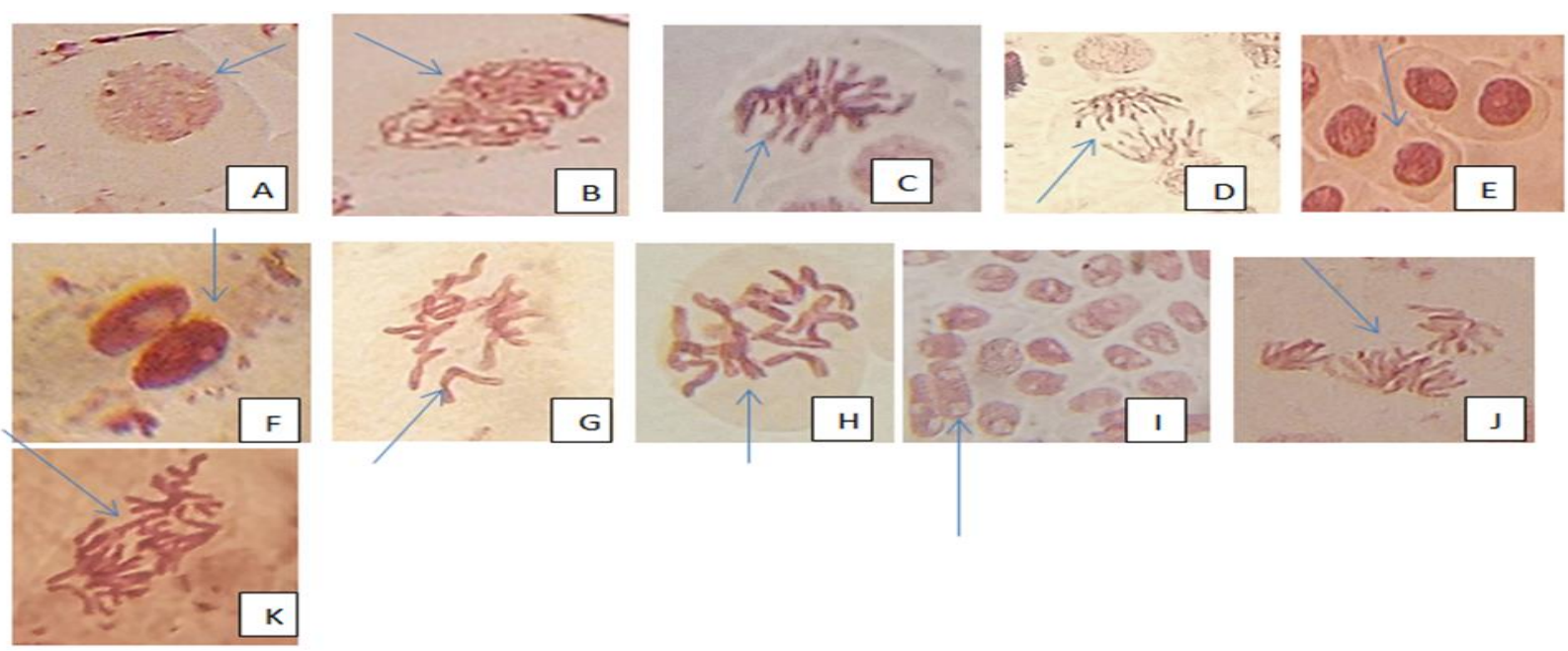

Figure 2 A -K Allium cepa root tip showing normal stages of mitotic division (A to E) and aberrant cells (F to K) from root tips treated with different concentrations of cassava industrial effluent.

(A) Normal interphase cell (B) Normal prophase cell (C) Normal metaphase (D) Normal anaphase (E) Normal telophase (F) Binucleate cell (G) Variant chromosomes (H) C-mitosis (I) Vacuolated cell (J) Tripolar anaphase (K) Anaphase bridge.

\section{Discussion}

Industrial effluent constitutes the major direct source of pollutant into aquatic environment with long term implications on sustainability of the ecosystem [31]. The fact that effluent obtained after extraction of ethanol from cassava contained Cadmium ( $\mathrm{Cd}$ ) and Lead $(\mathrm{Pb})$ higher than the minimum values recommended by World Health Organization indicates that effluent discharged by the industry is hazardous. This finding strongly suggests that effluent from the industry was not treated and therefore not safe for fishing and agricultural purposes. The high Cadmium (Cd) and Lead (Pb) contents recorded in this study calls for concern because [32] reported that Cadmium (Cd) is very toxic even at extremely low concentrations. According to them, there is positive correlation between the rate of renal disorder typified by tubular proteinuria in humans and duration of exposure to Cadmium. On the other hand, [33] reported that Lead (Pb) is one of the most pronounced hazardous heavy metals capable of causing teratogenic disorder when ingested into human systems through water and food. 
The fact that the total number of cells, numbers of prophase and anaphase cells did not show statistical significant differences among the different concentration of the effluent and control suggests that the effluent does not create or destroy available cells neither does it affect cells at these two stages of cell division (prophase and anaphase). Alege [34] gave similar report on different concentrations of aqueous extracts of Cola nitida where numbers of cells at interphase, prophase, anaphase and telophase stages did not vary significantly in relation to control.

This study revealed the clear effect of cassava industrial effluents on cell division and expression of chromosomal aberrations in Allium cepa root tip cells. The observed binucleate cells, variant chromosomes, C-mitosis, vacuolated cells, tripolar anaphase and anaphase bridge indicates mutagenic potential of the cassava industrial effluent studied. By comparison, variant chromosome, C-mitosis and Anaphase bridge induced by cassava industrial effluent on Allium cepa root meristems in this study have been previously reported by [4, 17, 21, 27, 35, 36, 37 and 38] as chromosomal abnormalities associated with effluents from bottling, cassava processing, textile, pharmaceutical, silk dyeing, textile, dyeing and pharmaceutical industries respectively. This suggests that the three chromosomal defects (variant chromosome, C-mitosis and Anaphase Bridge) may be induced by effluents generally.

This study also revealed decrease in the Mitotic Indices (MI) of effluent - treated root cells compared to the control which indicates mito-depressive potential of the effluent at every concentration. This observed reduction in Mitotic Index is in agreement with the reports of $[4,17,27,37]$ who observed decrease in Mitotic Indices of effluent - treated Allium cepa root tip cells compared to control. Kumari and Tripathi [27] opined that the reduction in Mitotic Index in chemical-treated Allium cepa root cells could be as a result of the effect of toxic chemicals on the synthesis of DNA or protein.

The significant increasing occurrence of chromosomal aberration in root cells of Allium cepa treated with the cassava industrial effluent and the absence of aberrations in control indicates the mutagenic nature of the effluent. Udebuani et al. [38] attributed the induction of chromosomal aberrations by industrial effluent to the high concentration of heavy metals in them. Abu [39] opined that the presence of heavy metals and cyanide in industrial effluents could be implicated as potentially mutagenic substances that would eventually find their way into man through consumption of plants and aquatic organisms from such polluted water bodies. The absence of chromosomal aberration in control coupled with the significant variations observed for the six aberrant conditions observed across the different concentrations of cassava industrial effluent suggests that the induction of chromosome abnormalities in this study is concentration dependent. As expected, the $100 \%$ concentration is obviously the most mutagenic in this study. This study therefore supported the use of Allium cepa assay for screening and monitoring of hazardous pollutants in the environment.

\section{Conclusion}

This study revealed the mutagenic and cytotoxic ability of cassava industrial effluent. Every concentration of the effluent has been found to be mutagenic although $100 \%$ concentration is found to be most mutagenic. The aberrations observed in this study may be linked to the high Cadmium (Cd) and Lead (Pb) concentrations of the studied effluent. Evidence from this study strongly suggests that the effluent was not treated before being discharged into the water body. This practice of discharging untreated effluent into the water bodies will obviously have serious health and environmental implications. Periodic monitoring of industries for compliance to treatment of effluent before being discharged to the environment is highly recommended because of the mutagenic and cytotoxic potential of cassava industrial effluent reported in this study.

\section{Compliance with ethical standards}

\section{Acknowledgments}

Authors are grateful to every contributors.

\section{Disclosure of conflict of interest}

The authors declared no conflict of interest.

\section{References}

[1] Abu NE, Ezeugwe SC. Risk Evaluation of Industrial Wastewater on Plants Using Onion (Allium cepa) Chromosome Aberration Assay. Journal of Tropical Agriculture, Food, Environment and Extension. 2008; 7(3): 242-248. 
[2] Siyanbola TO, Ajanaku KO, James 00, Olugbuyiro JAO, Adekoya JO. Physico-chemical characteristics of industrial effluents in Lagos State, Nigeria. G. J. P \& A Sc. and Tech. 2011; 1: 49-54.

[3] Komolafe RJ, Ajiboye AA, Agbolade JO, Cornelius 00. Evaluation of Cytotoxic and Phytotoxic Potentials of "Chi Limited" Industrial Effluent on Allium Cepa and Vigna unguiculata. Cytology and Histology International Journal. 2018; 2(1): 1-9.

[4] Olorunfemi DI, Ogieseri UM, Akinboro A. Genotoxicity Screening of Industrial Effluents Using Onions bulbs (Allium cepa L). Journal of Applied Science Management. 2011; 15(1): 211-216.

[5] Aniyikaiye TO, Oluseyi T, Odiyo JO, Edokpayi JN. Physico-chemical analysis of wastewater discharge from selected paint industries in Lagos, Nigeria. International Journal of Environmental Research and Public Health. 2019; 16: 1-17.

[6] Ogunkeyede AO, Okorhi-Damisa FB, Tedjere E, Sheyi A. Identication and morphology of pathogens in liquid effluent from a Cow dung biodigester. Issues in Biological Sciences and Pharmaceutical Research. 2020; 8(3): 5157.

[7] Gautam S, Saini G. Use of natural coagulants for industrial wastewater treatment. Global Journal of Environmental Science and Management. 2020; 6(4): 553-578.

[8] Naveedullah MZH, Chunna Y, Hui S, Dechao D, Chaofeng S, Liping L, Yingxu C. Concentrations and human health risk assessment of selected heavy metals in surface water of the siling reservoir watershed in Zhejiang Province, China. Polish Journal of Environmental Studies. 2014; 23(3): 801-811.

[9] Siddiqui S. DNA damage in Cicer plant grown on soil polluted with heavy metals. Journal of King Saud University - Science. 2015; 27: 217-223.

[10] Agbasah W, Boohene M. Levels of mercury in some commonly consumed fish in Ghana and their potential health risk to consumers. Saudi Journal of Life Science. 2018; 3(3): 269-276.

[11] Belmond BNE, Menbohan F, Josephine SN, Zakari MN, Rollinat MB, Jean D, Oumar OM, Carine T, Or MND, Serge MB. Chamberline N. Water quality assessment in a less anthropogenic forest stream in the Centre Region of Cameroon. Saudi Journal of Life Science. 2020; 5(1): 1-8.

[12] Boohene M, Agbasah W. Levels of heavy metals in water, fish (Oreochromis niloticus) and sediment from the Afram River, Ghana. Saudi Journal of Life Science. 2020; 3(3): 259-268.

[13] Iloms E, Ololade 00, Ogola HJO, Selvarajan R. Investigating industrial effluent impact on municipal wastewater treatment plant in Vaal, South Africa. International Journal of Environmental Research and Public Health. 2020; 17:1-18.

[14] World Health Organization. Guidelines for drinking-water quality 3rd Ed., Geneva: WHO Press. 2008.

[15] Reza R, Singh G. Heavy metal contamination and its indexing approach for river water. International Journal of Environmental Science and Technology. 2010; 7(4): 785-792.

[16] Ahmed S, Aktar S, Zaman S, Jahan RA, Bari ML. Use of natural bio-sorbent in removing dye, heavy metal and antibiotic-resistant bacteria from industrial wastewater. Applied Water Science. 2020; 10: 107-116.

[17] Ogunyemi AK, Samuel TA, Amund 00, IIori MO. Toxicity and Evaluation of Waste Effluent from CassavaProcessing. Ife Journal of Science. 2017; 20(2): 305-315.

[18] Osunde ZD, Fadeyibi A. Storage methods and some used of cassava in Nigeria. Continental Journal of Agricultural Sciences. 2011; 5(2): 12-18.

[19] Awoyale W, Abass AB, Ndavi M, Maziya-Dixon B, Sulyok M. Assessment of the potential industrial applications of commercial dried cassava prodicts in Nigeria. Food Measure. 2017; 11: 598-609.

[20] Egurefa SO, Orji MU, Uba BO. Toxic effect of refinery industrial effluent using three toxicity bioassays. South Asian Journal of Research in Microbiology. 2020; 6(2): 10-23.

[21] Wijeyaratne WMDN, Wickramasinghe PGMU. Chromosomal Abnormalities in Allium cepa Induced by Treated Textile Effluents: Spatial and Temporal Variations. Journal of Toxicology. 2020; 20: 1-9.

[22] Arimieari LW, Jaja GWT. Characteristics and control of effluents generated from industries in Port Harcourt, Nigeria. American Journal of Engineering Research. 2019; 8(2): 7-11. 
[23] Anjana S, John TE. Analysis of cytotoxic potential of the aqueous leaf extract of Pogostemon auricularius (L). Hassk using Allium cepa root tip assay, International Journal of Research and Development in Pharmacy and Life Sciences. 2013; 2(5): 562-566.

[24] IIbas AI, Umut G, Semih Y, Mehmey YD. Cytotoxicity of Aloe vera exracts on Allium cepa root tip cells. Turkish Journal of Botany. 2012; 36: 263-268.

[25] Alege GO, Egwuda RE. Cytotoxic effects of toner powder on Allium cepa root meristems. Proceedings of 38th annual conference of Genetics Society of Nigeria (GSN), Benin, Edo State. October 2014; 19-23.

[26] Padmanabha B. The impact of industrial effluents on the cell division of Allium cepa. Indian Journal of Research. 2017; 6(11): $629-630$.

[27] Kumari V, Tripathi, AK. Characterization of pharmaceuticals industrial effluent using GC-MS and FT-IR analyses and defining its toxicity. Applied Water Science. 2019; 9: 185-191.

[28] Tiwari MK, Bajpai S, Dewangan UK, Tamrakar RK. Assessment of heavy metal concentrations in surface water sources in an industrial region of central India. Karbala International Journal of Modern Science. $2015 ; 1: 9$-14.

[29] Akinyele B0. Meiotic Chromosome behavior and Sexual Sterility in two Nigerian species of Aloe. Linn. African Journal of Biotechnology. 2007; 6: 2585 - 2589.

[30] Malode SN, Lande SR. Shelke PB. Cytotoxic effects of Mimosa pudica L. leaf extract on Allium cepa root tips cells. International Journal of Biosciences. 2012; 2(3): 104-108.

[31] Abu NE, Mba KC. Mutagenecity testing of pharmaceutical effluents on Allium cepa root tip meristems. Journal of Toxicology and Environmental Health Science. 2011; 3(2): 44-51.

[32] Verma R, Dwived P. Heavy metal water pollution: A case study. Recent Research in Science and Technology. 2013; 5(5): 98-99.

[33] Krishnaswamy K, Kumar BD. Lead toxicity. Indian Journal of Pediatrics. 1998; 35: 209-216.

[34] Alege GO. Studies on Cytotoxicity Induced by Aqueous Extracts of Cola nitida (Kolanut) on Allium cepa (Onion). International Journal of Applied Biological Research. 2016; 7(2): 51 - 59.

[35] Sudhakar R, Gowda KN, Venu G. Mitotic abnormalities induced by silk dyeing industry effluents in the cells of Allium cepa. Cytologia. 2001; 66: 235-239.

[36] Samuel OB, Osuala F, Odeigah PGE. Cytogenotoxicity evaluation of two industrial effluents using Allium cepa assay. African Journal of Environmental Science and Technology. 2010; 4(1):21-27.

[37] Jairajpuri M, Raval R, Patel K. Chromosomal aberrations in root meristems of Allium cepa L. induced by dyeing industrial effluent. International Journal of Multidisciplinary Research and Development. 2016; 3(6): $272-275$.

[38] Udebuani AC, Ofoma AO, Otitoju O, Abara PN, Ezejiofor TN, Chukwuma MC. Cytotoxic and Genotoxic Impacts of Pharmaceutical Effluent from KP Pharmaceutical Industry, Nigeria. American Chemical Science Journal. 2016; 16(2): 1-10.

[39] Abu NE. Cytogenotoxicity effects of industrial effluents on Allium cepa root meristem: A review on positive results and problems of effective compliance to environmental legislations; the Nigeria perspective. Journal of Toxicology and Environmental Health Sciences. 2012; 4(10): 162-170. 